Brit. F. vener. Dis. (1968), 44, 315.

\title{
THE PROBLEM OF PENICILLIN RESISTANT GONOCOCCI*†
}

\author{
BY \\ C. S. NICOL, M. RIDLEY, AND M. A. E. SYMONDS
}

The incidence of relative resistance to penicillin among gonococci appears to have been increasing for some years. This study was undertaken in order to reassess the occurrence of penicillin resistant strains in one clinic and to correlate this with the incidence of failure of a single dose of penicillin to cure gonococcal urethritis in the male.

\section{Clinical \\ Material and Methods}

Between August and September, 1966, 98 cultures yielding gonococci were obtained from 98 consecutive male patients in whom a diagnosis of gonococcal urethritis had been made by examination of stained smears.

Diagnosis, treatment, and assessment of these patients were carried out by the staff of the Venereal Diseases Department at St. Thomas' Hospital. Diagnosis was based on findings in Gram-stained urethral smears made by the clinic staff and assessment of the result of treatment was made by the same staff, who worked without knowledge of the culture results or of the penicillin sensitivity of the isolates. Treatment consisted of one intramuscular injection of 600,000 units of procaine penicillin. Patients were followed up for 3 months and serological tests for syphilis were done at the first and last visit to the clinic. If gonococci reappeared during follow-up and the reappearance was considered to be due to relapse, then Triplopen (Glaxo) 2.5 million units was given; this preparation is a mixture of benzathine penicillin (40 per cent.), procaine penicillin (20 per cent.), and sodium benzyl penicillin (40 per cent.); it is claimed that a single dose maintains therapeutic concentrations for 3 to 4 days. If, however, the reappearance of the gonococci was thought to be due to re-infection, the routine treatment of 600,000 units of procaine penicillin was simply repeated. The distinction between relapse and re-infection is discussed later in this paper. If penicillin treatment unmasked a co-incident non-gonococcal infection, this was treated

* Paper read to the MSSVD on March 31, 1967.

+ Received for publication August 9, 1968. in the first instance with tetracycline $500 \mathrm{mg}$. three times a day by mouth for 5 days.

\section{Bacteriological}

Urethral swabs were sent to the laboratory in Stuart's transport medium. Neisseria gonorrhoeae were isolated on hydrocoele or chocolate agar plates and identified by standard sugar reactions. The minimal inhibitory concentrations (MICs) of penicillin were determined by making doubling dilutions of the antibiotic in chocolate agar plates; the plates were inoculated with a multiple inoculating device delivering approximately $0.03 \mathrm{ml}$. of a heavy suspension of each strain on to the plates. The plates were incubated for $\mathbf{2 4}$ hours in an atmosphere of 5 per cent. $\mathrm{CO}_{2}$ and the MIC was read as the lowest concentration of antibiotic which caused total inhibition of growth; the Oxford staphylococcus and resistant gonococci from previous test batches were always included on all plates as controls.

\section{Results}

\section{Clinical Results}

In 91 patients the initial gonococcal urethritis was treated routinely as described. These patients are classified by age and race in Table I. Seven other patients were treated differently for various reasons (e.g. because of penicillin hypersensitivity or the presence of a genital lesion suspected of being syphilitic) and are, therefore, not considered further.

\section{TABLE I}

CLASSIFICATION OF PATIENTS BY AGE, RACE, AND MEANS OF ACQUIRING INFECTION

\begin{tabular}{|c|c|c|c|}
\hline \multicolumn{2}{|c|}{ Classification } & \multicolumn{2}{|c|}{ No. of Patients } \\
\hline Age (yrs) & $\begin{array}{l}\text { Under } 24 \\
24 \text { and over }\end{array}$ & $\begin{array}{l}22 \\
69\end{array}$ & 91 \\
\hline Race & $\begin{array}{l}\text { White } \\
\text { Negro } \\
\text { Other }\end{array}$ & $\begin{array}{r}48 \\
35 \\
8\end{array}$ & 91 \\
\hline Source of Infection & $\begin{array}{l}\text { Heterosexual } \\
\text { Homosexual }\end{array}$ & $\begin{array}{r}84 \\
7\end{array}$ & 91 \\
\hline
\end{tabular}


As expected, the follow-up of patients posed a problem; the extent of the follow-up actually achieved is shown in Table II.

TABLE II

FOLLOW-UP, AND APPARENT RESULT OF ROUTINE TREATMENT

\begin{tabular}{l|c|c|c}
\hline Type of Follow-up & $\begin{array}{c}\text { Total } \\
\text { No. of } \\
\text { Cases }\end{array}$ & $\begin{array}{c}\text { Treatment } \\
\text { presumed } \\
\text { successful }\end{array}$ & $\begin{array}{c}\text { Post-treatment } \\
\text { Gonorrhoea } \\
\text { due to Relapse or } \\
\text { Re-infection }\end{array}$ \\
\hline $\begin{array}{c}\text { (1) None } \\
\text { (2) Returned at least } \\
\text { once but defaulted } \\
\text { before 3 weeks }\end{array}$ & 44 & 4 & 22 \\
\hline $\begin{array}{c}\text { (3) Followed-up for } \\
\text { at least 3 weeks }\end{array}$ & 43 & 21 & 22 \\
\hline Total & 91 & 69 & \\
\hline
\end{tabular}

The distinction between relapse and re-infection in those in whom the gonococcus reappears is arbitrary to a considerable extent. Evans (1966) defined relapse as follows: "If the gonococci reappear within 14 days of treatment and if further sexual intercourse is denied by the patient." We have followed these criteria so that a reasonable comparison can be made between our results and those of Evans.

The incidence of post-treatment gonorrhoea is shown in Table III. Of the 91 patients given an initial dose of 600,000 units of procaine penicillin nearly a quarter were subsequently found to have gonococci in urethral smears. Of these thirteen (14.3 per cent.) were classified as relapses, and nine $(9.8$ per cent.) as re-infections. Evans (1966) found a relapse rate of 11.4 per cent. in 2,258 male patients who had been given the same treatment at three different centres during 1962-63.

\section{Bacteriological Results}

The minimal inhibitory concentrations of benzyl penicillin for the 91 strains of $N$. gonorrhoeae are
TABLE III

POST-TREATMENT GONORRHOEA (RELAPSES AND RE-INFECTIONS)

\begin{tabular}{l|c|c}
\hline \multicolumn{1}{c|}{ Patients } & Number & $\begin{array}{c}\text { Percentage } \\
\text { of those Treated }\end{array}$ \\
\hline Number treated & 91 & 100 \\
\hline Relapses & 13 & $14 \cdot 3$ \\
Re-infections & 9 & $9 \cdot 8$ \\
\hline Total post-treatment gonorrhoea & 22 & $24 \cdot 1$ \\
\hline
\end{tabular}

shown in Table IV. No less than 37.3 per cent. of these strains were classified as relatively resistant with MICs of $0.1 \mu \mathrm{g} . / \mathrm{ml}$. or more. This is a much higher incidence of resistance than previously reported in Great Britain by Cradock-Watson, Shooter, and Nicol (1958), Curtis and Wilkinson (1958), Letchner and Nicol (1960), and the M.R.C. Working Party (1961). It is, however, very similar to the incidence reported more recently from Australia by Smith and Levey (1967). These various reports are compared in Table V. It should be noted that in this study we have followed the practice of reporting results in $\mu \mathrm{g} . / \mathrm{ml}$., whereas

TABLE V

REPORTS OF RELATIVE RESISTANCE TO PENICILLIN OF N. GONORRHOEAE

\begin{tabular}{l|c|c|c|c}
\hline \multicolumn{1}{c|}{ Authors } & Date & $\begin{array}{c}\text { Year } \\
\text { of } \\
\text { Study }\end{array}$ & $\begin{array}{c}\text { No. of } \\
\text { Strains } \\
\text { Tests }\end{array}$ & $\begin{array}{c}\text { Percentage } \\
\text { Relatively } \\
\text { Resistant } \\
\text { to Penicillin }\end{array}$ \\
\hline Curtis and Wilkinson & 1958 & 1958 & 302 & $19 \cdot 5$ \\
\hline $\begin{array}{l}\text { Cradock-Watson } \\
\text { Shooter and Nicol }\end{array}$ & 1958 & 1958 & 200 & $19 \cdot 0$ \\
\hline Letchner and Nicol & 1960 & 1960 & 99 & $8 \cdot 8$ \\
\hline MRC Working Party & 1961 & $1959-60$ & 1984 & $13 \cdot 2$ \\
\hline Present Study & 1968 & 1966 & 91 & $37 \cdot 3$ \\
\hline Smith and Levey & 1967 & 1966 & 104 & $44 \cdot 0$ \\
\hline
\end{tabular}

TABLE IV

MINIMAL INHIBITORY CONC.ENTRATIONS OF BENZYL PENICILLIN FOR 91 STRAINS OF GONOCOCCI

\begin{tabular}{|c|c|c|c|c|c|c|c|c|c|c|}
\hline \multirow{2}{*}{$\begin{array}{l}\text { Presumed } \\
\text { Result of } \\
\text { Treatment }\end{array}$} & \multirow{2}{*}{$\begin{array}{c}\text { Source } \\
\text { of Strains }\end{array}$} & \multirow{2}{*}{$\begin{array}{l}\text { No. of } \\
\text { Strains }\end{array}$} & \multicolumn{7}{|c|}{ No. of Strains Inhibited by Penicillin ( $\mu \mathrm{g} . / \mathrm{ml}$.) } & \multirow{2}{*}{$\begin{array}{c}\text { Percentage of Strains } \\
\text { Relatively Resistant } \\
\text { (MICs } 0.1-0.5 \% \mathrm{~g} . / \mathrm{ml} \text {.) }\end{array}$} \\
\hline & & & 0.005 & 0.01 & 0.025 & $0 \cdot 05$ & $0 \cdot 1$ & $0 \cdot 2.5$ & 0.5 & \\
\hline \multirow{2}{*}{ Failure } & Relapses & 13 & & 1 & 1 & 1 & 2 & 6 & 2 & $76 \cdot 9$ \\
\hline & Re-infections & 9 & 2 & 1 & 2 & 1 & 1 & 2 & & $33 \cdot 3$ \\
\hline \multirow{3}{*}{ Successful } & $\begin{array}{l}\text { Followed } \\
\text { for } 3 \text { weeks } \\
\text { or more }\end{array}$ & 21 & 4 & 6 & 4 & 1 & 3 & 2 & 1 & $28 \cdot 5$ \\
\hline & $\begin{array}{l}\text { Followed } \\
\text { for less than } \\
3 \text { weeks }\end{array}$ & 44 & 7 & 13 & 5 & 6 & 7 & 5 & 1 & $29 \cdot 5$ \\
\hline & No follow-up & 4 & & & 2 & & & 1 & 1 & $50 \cdot 0$ \\
\hline \multicolumn{2}{|l|}{ Total Strains } & 91 & 13 & 21 & 14 & 9 & 13 & 16 & 5 & $37 \cdot 3$ \\
\hline
\end{tabular}


previous reports have been based upon units $/ \mathrm{ml}$. The degree of resistance reported here, is therefore, slightly greater than that in these previous reports, in which MICs between 0.125 and 0.5 units $/ \mathrm{ml}$. $(0.075$ to $0.3 \mu \mathrm{g} . / \mathrm{ml}$.) have been taken as indicating resistance.

It is clear from Table IV that there is a reasonable degree of correlation between the independent clinical assessment of patients in terms of relapse or re-infection and the presence of resistant strains in these same patients. Of thirteen patients classified by the clinic staff as relapses, ten were infected with resistant strains compared with only three of nine patients considered to be cases of re-infection. The possible dissemination of resistant strains by patients who defaulted must, however, be a cause for concern; 48 out of 91 patients defaulted before 3 weeks and fifteen of these patients were originally infected with resistant strains. Six patients who were infected with resistant strains and followed up for 3 weeks were, however, apparently cured by the standard treatment of 600,000 units of procaine penicillin.

\section{Discussion}

There is no doubt that penicillin resistance of $N$. gonorrhoeae has now become a major problem (Brit. med. F., 1968). The incidence of partially resistant strains has more than doubled in the last 10 years despite increasing awareness of the problem. Failure to cure with a single dose of 600,000 units of procaine penicillin is now too frequent and must lead to further dissemination of resistant strains. There are two possible methods of dealing with this problem; to increase the dose and duration of penicillin treatment or to use some alternative antibacterial therapy. Increase of the dose of penicillin has been progressively used but has not prevented the gradual increase in incidence of penicillin resistant strains. In this clinic the routine treatment with penicillin was increased from 300,000 units to 600,000 units in 1960 (Letchner and Nicol, 1961) and more recently the dose has again been raised to 2.5 million units.

The use of drugs other than penicillin has also been tried and more recently combinations of drugs have been advocated and tried both in vitro and in vivo with apparent success (Garrod and Waterworth, 1968; Csonka and Knight, 1967). The importance of this work lies in finding a simple, cheap, effective treatment that cures after the first and perhaps the only attendance of the patient. There is abundant evidence with other bacteria and even with $N$. gonorrhoeae itself, that withdrawal of the use of an antibacterial agent is followed by a decline in the incidence of strains resistant to that antibiotic. Restriction upon the use of benzyl penicillin was shown to lead to a reduction in penicillin resistant staphylococci (Barber, Csillag, and Medway, 1958) and a similar decline in sulphonamide resistant gonococci has almost certainly occurred since the replacement of sulphonamide by penicillin (Garrod and Waterworth, 1968).

It is important that the best alternative treatment of gonococcal urethritis be quickly found and used in place of penicillin therapy for a period in the hope that penicillin resistant strains become far less frequent. Such a policy would need to be widespread in order to have maximum effect.

\section{Summary}

To determine whether the incidence of strains of gonococci partially resistant to penicillin continues to increase, a sample survey was conducted in a central London Venereal Diseases Clinic in the latter part of 1966. 91 men with gonorrhoea were each treated with a single injection of procaine penicillin 600,000 units and in all cases isolates were tested for sensitivity to penicillin; a MIC of $0.1 \mu \mathrm{g} . / \mathrm{ml}$. was chosen as the level indicating partial resistance so as to correspond approximately with criteria used in similar previous investigations. Post-treatment gonorrhoea developed in 22 of the 91 cases. On clinical grounds thirteen were considered treatment failures and nine re-infections; partially resistant organisms had been isolated in ten of the thirteen cases of treatment failure but in only three of the nine cases of re-infection. The overall incidence of partially resistant organisms was $37 \cdot 3$ per cent. indicating that the increasing incidence continues.

\section{REFERENCES}

Barber, M., Csillag, A., and Medway, A. J. (1958). Brit. med. F., 2, 1377.

Brit. med. F. (1968). Editorial, 1, 398.

Cradock-Watson, J. E., Shooter, R. A., and Nicol, C. S. (1958). Brit. med.F., 1, 1091.

Csonka, G. W., and Knight, G. J. (1967). Brit. F. vener. Dis., 43, 161.

Curtis, F. R., and Wilkinson, A. E. (1958). Ibid., 34, 70.

Evans, A. J. (1966). Ibid., 42, 251.

Garrod, L. P., and Waterworth, P. M. (1968). Ibid., 44, 75.

Letchner, E. H., and Nicol, C. S. (1961). Ibid., 37, 158.

Medical Research Council Interim Report (1961). Lancet, 2, 226.

Smith, D. D., and Levey, J. M. (1967). Med. F. Aust., $1,849$. 
Le problème des gonocoques résistants à la pénicilline

\section{RÉSUMÉ}

Afin de déterminer si l'incidence des souches de gonocoques qui sont partiellement résistantes à la pénicilline continue à augmenter, un relevé d'échantillons de gonocoques a été fait dans un dispensaire de maladies vénériennes du centre de Londres dans les derniers mois de 1966. 91 hommes atteints de blennorragie avaient été chacun traité par une injection unique de 600,000 unités de procaïne pénicilline et dans tous ces cas des "isolates" avaient été testés pour leur sensibilité à la pénicilline; un
MIC de $0,1 \mu \mathrm{g} . / \mathrm{ml}$. était choisi comme niveau indiquant une résistance partielle afin de correspondre approximativement à des critères employés dans les recherches précédentes semblables. La blennorragie après traitement avait apparu chez 22 des 91 cas. Pour des raisons cliniques treize ont été considérés comme des cas d'insuccès au traitement et neuf comme des réinfections; des gonocoques partiellement résistants avaient été isolés chez dix des treize cas d'insuccès au traitement mais chez trois seulement des neuf cas de réinfection. Au total l'incidence des gonocoques partiellement résistants était de 37,3 pour cent indiquant que l'incidence qui va en augmentant continue dans cette direction. 